\title{
LA POLÉMICA EN EL DELITO DE FINANCIACIÓN DE PARTIDOS POLÍTICOS: LAS PUERTAS CONTINÚAN ABIERTAS
}

\author{
Rafael Rebollo Vargas*
}

Resumen: En el trabajo se analizan una serie de cuestiones estructurales del nuevo delito de financiación ilegal de partidos políticos, poniendo en evidencia no sólo la utilización de una técnica legislativa precipitada y defectuosa; sino, también, los vacíos punitivos que permiten a los partidos políticos continuar nutriéndose ilegítimamente de fondos, tanto públicos como privados, ya sea a través de sus propias fundaciones, de condonaciones de deuda, a través de donaciones de bienes inmuebles o mediante la financiación pública ilícita.

Palabras Clave: partidos políticos, financiación ilegal, condonaciones de deuda, fundaciones, financiación pública ilícita.

Recibido: octubre 2017. Aceptado: junio 2018

* Catedrático Acreditado de Derecho Penal. ORCID ID: 0000-0002-71492984.

Departamento de Ciencia Política y Derecho Pública. Facultad de Derecho de la Universidad Autónoma de Barcelona. Edifici B2, Bellaterra, Carrer de la Vall Moronta, S/N, 08193 Cerdanyola del Vallès, Barcelona. Email: rafael.rebollo@uab.cat 


\title{
THE CONTROVERSY IN THE CRIME OF FINANCING OF POLITICAL PARTIES: THE DOORS CONTINUE OPEN
}

\begin{abstract}
The paper discusses a number of structural issues concerning the new crime of illegal financing of political parties, by highlighting not only the use of a defective and hasty legislative technique; but also, the punitive loopholes that allow political parties to continue nurturing illegitimately funding, both public and private, through their own foundations, of debt forgiveness, real estate donations or illicit public financing.
\end{abstract}

Keywords: political parties, illegal financing, forgiveness of debt, foundations, illegal public funding.

\section{Notas preliminares}

Los delitos de financiación ilegal de los partidos políticos se integran en el Código penal mediante la L.O. 1/2015, de 30 de marzo, que incorpora un nuevo Título XIII bis con ese análogo epígrafe y constituido por dos nuevos artículos (304 bis y 304 ter $)^{1}$; es decir, se sitúan entre los Delitos contra el Patrimonio y el Orden Socioeconómico y los Delitos contra la Hacienda Pública y la Seguridad Social. Como observaremos más adelante, se trata de una posición sistemática, como poco, cuestionable, que ha generado importantes críticas doctrinales y que, en realidad, se estructura como un elemento más para corroborar que su tipificación fue poco reflexionada. No quiero decir con ello que no fuera ineludible ${ }^{2}$ pero sí que, técnicamente, se trata de unos preceptos claramente mejorables de los que se desprenden unos problemas interpretativos que no son sencillos de resolver.

1 En nuestro país, uno de los primeros trabajos sobre la materia fue el libro de ROMERO FLORES, B., Partidos políticos y responsabilidad penal. La financiación electoral irregular, Barcelona, 2005, quien realiza un detallado análisis de derecho comparado, así como de la legislación entonces vigente: la Ley orgánica sobre financiación de los partidos políticos, L.O. 3/1987, de 2 de julio, además de la Ley orgánica del régimen electoral general, L.O. 5/1985, de 19 de junio.

2 Al respecto, entre otros, MAROTO CALATAYUD, M., La financiación ilegal de los partidos políticos. Un análisis político-criminal, Madrid, 
Es un delito cuya tipificación no estaba recogida ni en el Anteproyecto, ni en el Proyecto de Ley Orgánica por el que se reformaba el Código penal, sino que su integración se produjo durante la tramitación parlamentaria que dio lugar a la L.O. 1/2015, de 30 de marzo. Es llamativo como en el Preámbulo de la nueva Ley se hace referencia a ello en el último párrafo del ordinal $\mathrm{XIX}^{3}$, donde se exponen las razones que motivaron las reformas: intensificar la punición de los "delitos contra la corrupción en el ámbito de la Administración pública", lo cual viene a confirmar las dudas que provoca -a las que entiendo, el legislador no es ajeno- su emplazamiento sistemático en el Código.

La criminalización de la financiación ilegal de los partidos políticos es una decisión de política criminal adoptada por la concurrencia de distintos factores que, en mi opinión, vino presidida por episodios que vislumbran una endémica corrupción en la financiación de casi todos los partidos ${ }^{4}$, que, inclusive,

2015, págs. 298 y ss.; OLAIZOLA NOGALES, I., La financiación ilegal de los partidos politicos: un foco de corrupción, Valencia, 2014, págs. 190 y ss; vid., GARCÍA ARÁN, M., "Sobre la tipicidad penal de la financiación irregular de los partidos políticos", en Derecho penal para un Estado Social y Democrático de Derecho (Estudios penales en homenaje al Profesor Emilio Octavio de Toledo y Ubieto), Madrid, 2016, en especial, págs. 601 y ss., donde la autora reflexiona acerca de la conveniencia de establecer un tipo penal autónomo de financiación ilegal de los partidos.

3 "Finalmente, la reforma introduce un nuevo Título XIII bis con la rúbrica «De los delitos de financiación ilegal de los partidos políticos», integrado por los dos nuevos artículos 304 bis y 304 ter, que da respuesta penal a la necesidad de definir un tipo penal específico para estos actos delictivos, ya que en la vigente legislación española no existe un delito concreto que esté tipificado como delito de financiación ilegal de partidos políticos. Con esta modificación se castigará a aquellas personas que acepten y reciban donaciones ilegales o que participen en estructuras u organizaciones cuyo principal objeto sea el de financiar ilegalmente a un partido político".

4 Vid. OLAIZOLA NOGALES, I., "Las reformas legales relacionadas con la financiación de los partidos políticos", en Corrupción pública prueba y delito: cuestiones de libertad e intimidad (JAREÑO LEAL. A. -DOVAL PAÍS, A. Directores), Pamplona, 2015, pág. 253, nota núm. 1, donde da cuenta de algunos de los episodios más conocidos que afectan a una buena parte del arco parlamentario de este país. 
han llevado a que el actual Presidente del Partido Popular (y del Gobierno) sea requerido a declarar como testigo en el caso Gürtel. Es más, lo que en un principio se advertía, y los propios partidos políticos así lo enfatizaban para desvincularse de lo que -decían- eran actuaciones individuales que nada tenían que ver con las respectivas organizaciones, se convierte en un problema sistémico que ha desintegrado estructuras, dirigentes y cargos políticos de los partidos más representativos de nuestro arco parlamentario. A lo precedente, cabe añadir que el Tribunal de Cuentas, el órgano que tiene el deber de fiscalizar esa financiación no parece, dada su composición, estructura y medios, que haya sido el más adecuado para cumplir la extraordinaria función que tiene encomendada.

Probablemente la percepción de la opinión pública por la progresión de escándalos relativos a las "Cajas B", al pago de "sobresueldos", al "caso del 3\%" o a tantos otros, además de la obligación de dar respuesta a algunas de las recomendaciones efectuadas por el $\mathrm{GRECO}^{5}$, tiene como consecuencia que en septiembre de 2013 el Gobierno aprobara un Plan de medidas de "regeneración democrática" que introducían, solo por referir algunas, la agravación de las sanciones aplicables a las infracciones relacionadas con la actividad de los partidos políticos, el refuerzo de la rendición de cuentas o la supervisión de la financiación de los partidos políticos mediante la ampliación de las competencias del Tribunal de Cuentas lo cual dio lugar a la reforma, mediante la misma Ley Orgánica 3/2015, de 30 de marzo, de control de la actividad económico financiera de los partidos políticos, de la Ley Orgánica 8/2007, de 4 de julio, sobre

5 Vid., Informe del GRECO. Anexo España al "Informe de lucha contra la corrupción en la Unión Europea”, Bruselas, 3 de febrero de 2014, págs. 5 y ss. Como es sabido, el Consejo de Europa creó el Grupo de Estados contra la Corrupción (GRECO), a quien se le encargó el seguimiento y control de las medidas adoptadas por el Consejo de Europa el 8 de abril de 2003 y firmadas por España. Los tres informes publicados concernientes a la situación en nuestro país $(2009,2011$ y 2013) no incitan, precisamente, al optimismo. 
financiación de Partidos Políticos; de la Ley Orgánica 6/2002, de 27 de junio, de Partidos Políticos, así como de la Ley Orgánica 2/1982, de 12 de mayo, del Tribunal de Cuentas, y, como consecuencia de todo ello, mediante la Ley Orgánica 1/2015, de 30 de marzo, por la que se modifica la Ley Orgánica 10/1995, del Código Penal, la integración al texto punitivo del delito de financiación ilegal de los partidos políticos aunque, como hemos dicho antes, su incorporación al Código penal no estaba prevista en el Anteproyecto ni el Proyecto de reforma del Código penal, por lo que los pormenores concretos del tipo penal propuesto sólo se supieron en la fase de enmiendas a la reforma del Código penal, siguiendo un "iter" legislativo diferenciado del citado Plan de medidas de renovación democrática.

Aunque hasta ese momento no existiera una tipificación expresa del delito de financiación ilegal de partidos políticos, no creo que pudiera sostenerse la existencia de un vacío puniti$\mathrm{vo}^{6}$, sino que en el proceso de financiación ilegal se consumaban otros delitos que sí estaban tipificados en el Código penal ${ }^{7}$, como podrían ser: prevaricaciones, falsedades, infidelidad en la custodia de documentos, tráfico de influencias, cohecho, delitos contra la Hacienda Pública, malversación de caudales públicos o, yendo más lejos, incluso se ha llegado a sugerir la probabilidad de imputar por el delito de asociación ilícita al no desdeñar que en algunos casos podrían concurrir elementos característicos de la criminalidad organizada ${ }^{8}$. En todo caso, en la actualidad,

6 MAROTO CALATAYUD, M., "Financiación ilegal de partidos políticos", en Comentario a la reforma penal de 2015, (QUINTERO OLIVARES, G., Director), Pamplona, 2015, pág. 756.

7 NÚÑEZ CASTAÑO, E., "La cuestionable regulación penal de los delitos de financiación ilegal de partidos políticos", en Revista Penal, n 39, 2017, pág. 128, quien habla de la "aplicación de manera creativa de algunos de los delitos cometidos en el Código penal".

8 Íbidem, nota a pie de pág. núm. 14. Igualmente, BUSTOS RUBIO, M., "El nuevo delito de financiación ilegal de partidos políticos", en Revista Penal, $\mathrm{n}^{\circ}$ 37, 2016, pág. 4; NAVARRO CARDOSO, F., "Corrupción, transparencia y Derecho penal. Especial referencia al derecho de acceso a la información pública”, en Cuadernos de Política Criminal, núm. 114, 2014, págs. 113-114. 
MAROTO CALATAYUD califica la actual situación de "atipicidad relativa", ya que la descripción típica de los arts. 304 bis y 304 ter del Código penal introduce una serie de variables que implican la atipicidad de las conductas que queden fuera de los arts. 5. Uno y 7. Dos de la Ley Orgánica 8/2007, sobre financiación de los partidos políticos (en adelante, LOFPP), es el caso de la financiación pública ilegal, de las donaciones a fundaciones, de las condonaciones parciales o totales de deudas a los partidos políticos, de las operaciones asimiladas, de las falsedades en la contabilidad del partido o de las donaciones estrictamente electorales, etc. ${ }^{9}$. Conductas que, necesariamente, deberán examinarse desde los tipos penales que se han empleado hasta este momento, a los que habría que incorporar las opciones que ofrece la redacción actual del delito de malversación de caudales públicos ${ }^{10}$.

El ámbito normativo del delito de financiación ilegal de los partidos políticos, sin perjuicio de la tipificación expresa de determinados comportamientos, no es demasiado halagüeño porque, en realidad, continuamos sumidos en esa "atipicidad relativa" o, en su caso, acudiendo a la "aplicación creativa" de algunos de los tipos penales clásicos, fundamentalmente, los Delitos contra la Administración Pública o los Delitos contra la Hacienda Pública. Al respecto, es necesario aludir a una excepción "aparente" ya que, es cierto, que en la Ley Orgánica 5/1985, de 19 de junio, Régimen Electoral General, se prevén en su Sección $2^{\mathrm{a}}$, Capítulo VIII, del Título I, una serie de delitos electorales,

9 PUENTE ABA, L.M., "Financiación ilegal de partidos políticos (art. 304 bis CP)", en Comentarios a la reforma del Código penal de 2015 (Director, GONZÁLEZ CUSSAC, J.L.), Valencia, 2015, págs. 1066 y ss. Igualmente, vid., MAROTO CALATAYUD, M., La financiación ilegal de los partidos políticos. Un análisis político-criminal, ob. cit., págs. 175 y ss.; OLAIZOLA NOGALES, I., La financiación ilegal de los partidos políticos: un foco de corrupción, ob. cit., págs. 130 y ss.

10 MAROTO CALATAYUD, M., La financiación ilegal de los partidos políticos. Un análisis político-criminal, ob. cit., págs. 175-176. 
entre los cuales se encuentra el art. $149^{11}$, falsificación de la contabilidad de los partidos, federaciones, coaliciones o agrupaciones de electores en campaña electoral, en el que se castiga el falseamiento de la contabilidad electoral para encubrir aportaciones irregulares ${ }^{12}$; si bien el colofón de ello es que no resulta rechazable que la falsificación de la contabilidad de los partidos políticos sea, en la actualidad, impune ${ }^{13}$. Impunidad que se deduce de la circunstancia que el delito societario de falsificación contable del art. 290 del Código penal no le resulta aplicable a los partidos políticos ya que, atención a lo previsto en el art. 297, éstos no pueden calificarse como sociedades ${ }^{14}$. Es más, tampoco le resultan aplicables las falsedades mercantiles del art. 392 del Código penal, ya que las falsedades en una contabilidad real, no ficticia, son impunes conforme al art. $390.1 .4^{\circ}$, pues no suponen un encubrimiento de su contabilidad ${ }^{15}$. Falsedades que tampoco cumplen con los requisitos del delito contable tributario del art. 310 del Código penal pero, sí así fuera, esto es, si el objeto de

11 Art. 149.1. "Los administradores generales y de las candidaturas de los partidos, federaciones, colaciones o agrupaciones de electores que falseen las cuentas, reflejando u omitiendo indebidamente en las mismas aportaciones o gastos o usando de cualquier artificio que suponga aumento o disminución de partidas contables, serán castigados con la pena de prisión de uno a cuatro años y multa de doce a veinticuatro meses.

2. Los Tribunales atendiendo a la gravedad del hecho y sus circunstancias podrán imponer la pena en un grado inferior a la señalada en el párrafo anterior".

12 PUENTE ABA, L.M., ob. cit., pág. 1067.

13 GÓMEZ BENÍTEZ, J.M. "Financiación ilegal de partidos políticos y corrupción”, en Prevención y tratamiento punitivo de la corrupción en la contratación, (CASTRO MORENO, A.-OTERO GONZÁLEZ, P., Directores), Madrid, 2016, pág. 152.

14 Al respecto, $V i d$. la interpretación realizada en su momento por de ROMERO FLORES, B., Partidos políticos y responsabilidad penal. La financiación electoral irregular, ob. cit., págs. 99 y ss.

15 Entre otras, vid., STS (Sala 2a), 211/2014, de 18 de marzo, FJ 3.3: “...Cuando se confecciona un documento para reflejar una realidad negocial existente, la introducción de datos falsos o inexactos constituiría un supuesto de falta a la verdad en la narración de los hechos, impune cuando el autor es un particular". 
las falsedades fuera defraudar a la Hacienda Pública, el delito desaparecería absorbido por el oportuno delito fiscal ${ }^{16}$.

Con independencia de lo anterior se debe poner de relieve que las modalidades delictivas de financiación ilegal de los partidos políticos se prevén en el art. 304 bis del Código penal, en cuyo apartado primero se dispone un tipo básico relativo a la financiación privada de los partidos políticos, además de dos figuras agravadas en el segundo apartado del mismo art. 304 bis. Asimismo, en el artículo 304 bis ter, se regula un tipo cualificado cuando la financiación ilegal de los partidos políticos, federaciones, coaliciones o agrupaciones electorales se realice a través de una estructura u organización específicamente destinado a tal fin.

\section{Algunos problemas interpretativos}

Previamente debo adelantar que las páginas que siguen no se van a dedicar a estudiar en sentido estricto los dos tipos penales del delito de financiación ilegal de los partidos políticos (arts. 304 bis y 304 ter), ni sus siete modalidades delictivas, sin perjuicio de que de forma puntual se aborde algún elemento estructural del tipo básico. El objeto de este trabajo es examinar otros problemas que lo desdibujan materialmente.

\subsection{Una controversia adicional: las leyes penales en}

\section{blanco.}

Una cuestión que ha suscitado importantes controversias doctrinales es la configuración típica del delito como una norma penal en blanco. Efectivamente, nos encontramos ante una norma penal en blanco que remite al art. 5. Uno de la L.O.

16 GÓMEZ BENÍTEZ, J.M. "'Financiación ilegal de partidos políticos y corrupción”, en Prevención y tratamiento punitivo de la corrupción en la contratación", ob. cit., pág. 152. Asimismo, MACÍAS ESPEJO, B., "Sobre la incriminación de la financiación ilegal de partidos políticos en el artículo 304 bis del Código penal”, en Cuadernos de Política Criminal, núm. 119, 2016, págs. 135-136; PUENTE ABA, L.M., Financiación ilegal de partidos políticos (art. 304 bis CP)”, ob. cit., págs. 1064 y 1067, 1072. 
8/2007, de 4 de julio, sobre financiación de los partidos políticos para delimitar el ámbito del comportamiento típico punible por lo que, en virtud de lo allí establecido, será constitutivo de delito "recibir" donaciones o aportaciones: a) anónimas, finalistas o revocables; b) las procedentes de una misma persona superiores a 50.000 euros anuales; y, c) las procedentes de personas jurídicas y de entes sin personalidad jurídica. Obsérvese que el Código penal se refiere a un comportamiento típico que reviste una única modalidad que es el "recibir", mientras que el art. 5.Uno, amplía las modalidades de comportamiento e incorpora, también, el "aceptar" junto al "recibir", lo cual ya nos ocasiona el primer problema en la interpretación del comportamiento penalmente ilícito.

Si retomamos las dudas que suscita la remisión normativa a la LOFPP, éstas, son de una indudable consideración. Así, desde quien entiende que la conducta determinante de la infracción penal se encuentra en la L.O. 8/2007, no en el tipo penal, lo cual le lleva a dudar de que se ajuste al principio de legalidad ${ }^{17}$; a quienes sostienen que la "prohibición penal" no queda suficientemente definida en una norma penal en blanco como el art. 304 bis, por lo que sería de "dudosa legitimidad" por violación del principio de legalidad ya que se hace particularmente complejo o, simplemente, es inviable con esa redacción determinar la lesividad penal expresada en el tipo de injusto de los arts. 304 bis y 304 ter para determinar su objeto jurídico de tutela ${ }^{18}$; a otros que ponen de relieve el hecho de que ciertos comportamientos que se encuentran fuera de la remisión expresa realizada por el Código penal a la LOFPP serán atípicos, criticando, además, que la modificación directa del contenido del injusto mediante la reforma

17 MUÑOZ CUESTA, F.J., "Delitos de financiación ilegal de partidos políticos”, en Revista Aranzadi Doctrinal, núm. 5/2015, pág. 2

18 SAINZ CANTERO CAPARROS, J.E., "Los delitos de financiación ilegal de los partidos políticos", en Estudios sobre el Código penal reformado (MORILLAS CUEVA, L., Director), Madrid, 2015, pág. 662, nota a pie de página núm. 4. 
de una "legislación administrativa" vulnera de manera clara y directa el principio de legalidad ${ }^{19}$; o los que, en línea similar a la anterior, ponen de relieve que quedan "aparentemente fuera del alcance del tipo" conductas de similar gravedad a las allí descritas, como es el caso de las condonaciones de créditos y las operaciones asimiladas (ex. la asunción de gastos del partido por parte de terceros), con la particularidad de que la LOFPP sí las contempla como infracciones, pero no el precepto penal ya que éstas se encuentran reguladas en el art. 4 de la LOFPP y no el art. 5.Uno al que remite el Código penal. En esa misma línea de consideraciones, se afirma que se situarían fuera del tipo conductas asimilables en su injusto material a las descritas en el tipo, como es el caso de las donaciones de inmuebles, a lo que se concluye que: "quedará así a la interpretación del juez penal, con la limitación de la prohibición de analogía y hasta cierto punto por la propia LOFPP, el determinar si este grupo de casos realmente merecen ser considerados atípicos" ${ }^{\prime 20}$.

Vaya por adelantado que, en una primera lectura, comparto la inquietud de que la configuración típica del precepto, en base a una remisión normativa expresa, se ajusta dudosamente al principio de legalidad. Ahora bien, en sentido contrario, me resulta discutible por suponer una vulneración palmaria del principio de legalidad que haya conductas que "quedan aparentemente fuera del tipo penal". El precepto remite únicamente al art. 5.Uno de la LOFPP, aunque haya comportamientos que con un desvalor asimilable a los descritos en el tipo quedan fuera. No creo que se trate de que merezcan ser típicos o atípicos, como más adelante veremos, a mi parecer lo determinante es que si las donaciones a las fundaciones vinculadas a los partidos políticos no están incluidas en la norma a la que se realiza la remisión normativa, esas conductas serán penalmente atípicas.

19 NUÑEZ CASTAÑO, E., La cuestionable regulación penal de los delitos de financiación ilegal de partidos políticos”, en Revista penal, n³ 39, 2017, pág. 130.

20 MAROTO CALATAYUD, M., "Financiación ilegal de partidos políticos", en Comentario a la reforma penal de 2015, ob. cit., pág. 762. 
Como acabo de referir, las dudas surgen con respecto a si la configuración típica del precepto vulnera el principio de legalidad. Para dirimir esa cuestión es inevitable realizar una aproximación al concepto de norma penal en blanco y a los requisitos que estable la Jurisprudencia del Tribunal Constitucional para su admisibilidad. Así, con carácter general, se puede afirmar que una norma penal en blanco es aquella en las que el supuesto de hecho no aparece descrito en su totalidad, debiendo acudirse para su complemento a otra norma o conjunto de normas de carácter no penal.

A partir de ahí no existe acuerdo doctrinal, ya que pueden diferenciarse diversos conceptos de norma penal en blanco en función del rango de la norma extrapenal complementadora o de remisión ${ }^{21}$. Así, un sector de la doctrina defiende un concepto estricto de ley penal en blanco, según el cual la remisión es a una norma de carácter inferior, reglamentario (sin que sea constitucionalmente admisible la incorporación al tipo penal, es decir, al ámbito de la prohibición mediante, por ejemplo, órdenes ministeriales). Se trata, por lo tanto, de una delegación a una autoridad inferior y es, precisamente, el hecho de que la determinación del hecho punible se realiza a una norma inferior a la ley, cuestión que plantea dudas con respecto a su compatibilidad con el principio de legalidad ${ }^{22}$.

Un criterio distinto, seguramente mayoritario en la doctrina ${ }^{23}$, es el que asume un concepto amplio de ley penal en blan-

21 MIR PUIG, S., Derecho penal. Parte General, $10^{\mathrm{a}}$ ed. (2 $2^{\mathrm{a}}$ reimpresión), 2016, págs. 72 y ss. Vid., igualmente, HUERTA TOCILDO, S., "Principio de legalidad y normas sancionadoras", en El principio de legalidad. Actas de las V Jornadas de la asociación de Letrados del Tribunal Constitucional, Madrid, 2000, pág. 22, nota a pie de página núm. 19.

22 LUZÓN PEÑA, D.M., Lecciones de Derecho Penal, $3^{\text {a }}$ edición, ampliada y revisada, Valencia, 2016, pág. 60. Igualmente, Vid., SANTANA VEGA, D.M., El concepto de ley penal en blanco, Buenos Aires, 2000, págs. 27 y ss.

23 Al respecto, Vid., GARCÍA ARÁN, M., "Remisiones normativas, leyes penales en blanco y estructura de la norma penal", en Estudios penales y Criminológicos, XVI, 1992-1993, pág. 66. 
co que supone que la norma extrapenal de remisión es un reglamento o una ley ${ }^{24}$, lo cual entroncan con cuestiones tanto dogmáticas (tratamiento del error y retroactividad o irretroactividad de la ley penal), como con principios político criminales ya que es preferible, afirman, que la delimitación del ámbito punible se haga con arreglo a los principios específicos del Derecho penal y no se deje esa misión a normas extrapenales, incluso aunque sean leyes.

En efecto, las dudas sobre la constitucionalidad de las normas penales en blanco, básicamente, se producen cuando el reenvío tiene lugar a otra norma que no tiene carácter de ley en sentido formal, dando así entrada en la descripción típica del comportamiento punible a regulaciones de procedencia reglamentaria ${ }^{25} \mathrm{y}$, por lo tanto, a una participación del poder ejecutivo en la configuración de las conductas prohibidas. Se trata de una cuestión sobre la que existe una doctrina consolidada en el Tribunal Constitucional quien, como es sabido, destaca que el principio de legalidad penal, en su vertiente de garantía de orden formal, obliga a que sea precisamente una norma con rango de ley la que defina las conductas delictivas y señale las penas correspondientes. No obstante, la reserva de ley en materia pe-

24 DOVAL PAÍS, A., Posibilidades y límites para la formulación de las normas penales. El caso de las leyes en blanco, Valencia, 1998, págs. 98 y ss.

25 Vid. STC 283/2006, 9 de octubre de 2006, FJ 6: "Y en este caso, resulta de aplicación la doctrina sentada en la STC 24/2004, de 24 de febrero, en la que declarábamos que aunque "la reserva de ley en materia penal no excluye la posibilidad de que sus términos se complementen con lo dispuesto en leyes extrapenales y reglamentos administrativos, en el presente supuesto tal posibilidad debe agotarse en el Real Decreto 137/1993, de 29 de enero (o la norma que en el futuro lo sustituya) sin que pueda considerarse constitucionalmente admisible, a los efectos de la configuración del tipo penal, la incorporación al mismo de lo prohibido mediante órdenes ministeriales, conforme a lo previsto en la anteriormente transcrita disposición final cuarta del mismo ... porque de lo contrario, por esa vía se diluiría de tal modo la función de garantía de certeza y seguridad jurídica de los tipos penales, función esencial de la reserva de ley en materia penal, que resultaría vulnerado el art. 25.1 CE" (FJ 3). 
nal no impide, afirma, la existencia de las denominadas leyes penales en blanco. Se trata de "normas penales incompletas que no describen agotadoramente la correspondiente conducta o su consecuencia jurídico-penal, sino que se remiten para su integración a otras normas distintas, que pueden ser incluso de carácter reglamentario". Ahora bien, para que esa remisión a normas extrapenales sea admisible constitucionalmente debe cumplir en todo caso los siguientes requisitos: a) que el reenvío normativo sea expreso y esté justificado en razón del bien jurídico protegido por la norma penal; b) que la ley, además de señalar la pena, contenga el núcleo esencial de la prohibición ${ }^{26}$; y c), sea satisfecha la exigencia de certeza, esto es, que "la conducta calificada de delictiva quede suficientemente precisada con el complemento indispensable de la norma a la que la ley penal se remite, y resulte de esta forma salvaguardada la función de garantía de tipo con la posibilidad de conocimiento de la actuación penalmente conminada" (STC 127/1990, de 5 de julio, FJ 3).

Junto a la citada garantía formal, el principio de legalidad penal del art. 25.1 CE precisa una garantía de carácter material que refleja la especial trascendencia del principio de seguridad jurídica en este ámbito limitativo de la libertad individual que, en relación con el legislador y por lo que ahora interesa, se traduce en la exigencia absoluta de la predeterminación normativa de las conductas ilícitas y de las sanciones correspondientes mediante una tipificación lo más precisa y taxativa posible en la descripción que incorpora para que, de este modo, "los ciudadanos puedan conocer de antemano el ámbito de lo prohibido y prever, así, las consecuencias de sus acciones" (STC 283/2006, de 9 de octubre, FJ 5).

Una vez esbozados los criterios fijados por el Tribunal Constitucional para la admisibilidad de las leyes penales en

26 GARCÍA ARÁN, M., "Remisiones normativas, leyes penales en blanco y estructura de la norma penal", ob. cit., págs. 85 y ss. Igualmente, GERPE LANDÍN, M., "Principio de legalidad y remisiones normativas en materia penal”, en Revista Jurídica de Cataluña, 1991, pág. 699. 
blanco, creo que seguidamente hemos de adoptar todas las precauciones y matices necesarios. En efecto, el art. 304 bis del Código penal remite expresamente, para definir el núcleo esencial de la prohibición, a una norma de carácter administrativo, sin ninguna otra exigencia adicional que justifique el recurso a la sanción penal. Y, sí, es cierto que el Código penal es una norma con rango de Ley Orgánica que remite a otra norma con el mismo rango de Ley Orgánica ${ }^{27}$, al artículo 5.Uno de la LOFPP. En este sentido, el Tribunal Constitucional se ha pronunciado sobre el rango de la norma de complemento en contadas ocasiones, pero cuando lo ha hecho ha sido inequívoco al considerar que la Constitución ni impone ni prohíbe que el complemento extrapenal de una ley punitiva en blanco haya de estar previsto por una disposición que tenga el rango de Ley Orgánica. Se trata, afirma, de una decisión que normalmente, salvo que venga impuesta por la Constitución en virtud de otros motivos, queda en manos del legislador. Es más, concluye, no existe una reserva de Ley Orgánica para el complemento de las leyes penales ${ }^{28}$.

No obstante, cabe seguir preguntándose: ¿el hecho de que ambas normas tengan el mismo rango diluye los problemas de indeterminación normativa que se suscitan como consecuencia de una remisión interpretativa en bloque? La cuestión, a mi entender, es particularmente compleja además de que no me consta un supuesto de remisión normativa a otra Ley Orgánica en nuestro actual Código penal.

Con independencia del rango normativo de ambas leyes no es posible apreciar ningún elemento diferencial entre el ilíci-

27 DOVAL PAÍS, A., Posibilidades y límites para la formulación de las normas penales. El caso de las leyes en blanco, ob. cit., págs. 120-121

$28 \mathrm{Al}$ respecto $\mathrm{Vid}$., STC 118/1992, de 16 de septiembre, FJ 2, donde el Alto Tribunal considera que: “...Esta exigencia de Ley formal para las normas penales, que resulta del art. 25.1 C.E. no implica, por sí sola, la necesidad de que las normas penales hayan de revestir rango de Ley orgánica (STC 25/1984). Pero sí existe reserva constitucional en favor de la ley orgánica, de conformidad con lo dispuesto en el art. 81.1, en relación con el art. 17.1 C.E., respecto de las normas penales que establezcan penas privativas de libertad". 
to penal y el ilícito administrativo, con la particularidad de que la previsión penal incorpora penas privativas de libertad que oscilan entre los seis meses y los cuatro años, pudiendo imponerse en su mitad superior -si los hechos revisten especial gravedad-e incluso alcanzar la pena superior en grado, lo que suscita un problema de proporcionalidad de la reacción penal. Añádasele a lo anterior que es cuestionable el establecimiento de sanciones penales cuando el recurso a la sanción administrativa puede ser suficiente para la consecución de las finalidades deseadas por el legislador (STC 55/1996, FJ 8) ya que, como es sabido, la sanción penal sólo será necesaria cuando no existan otras vías de protección alternativas en el ordenamiento jurídico que resulten menos restrictivas de derechos $\mathrm{y}$, desde luego, resulten idóneas para obtener la finalidad deseada (principio de ultima ratio).

Retomando la reflexión inicial me resulta inevitable cuestionar si es lícita una remisión ciega a la norma administrativa ${ }^{29}$, por mucho que ésta disponga también del rango de Ley Orgánica, o si el hecho de que se incurra en alguna de las infracciones previstas en el art. 5.Uno de la LOFPP, supone la creación de un ilícito meramente formal que penaliza el incumplimiento de una prohibición administrativa y más cuando no existe ningún elemento que permita diferenciar la infracción penal de la infracción administrativa. Creo, por otro lado, que en el art. 304 bis del Código penal no se contiene el núcleo esencial de la prohibición, ya que la vinculación-remisión del contenido normativo del precepto a la normativa administrativa es absoluta e incondicional.

Es cierto que ambas Leyes poseen el rango de Orgánicas, que precisan de mayorías cualificadas para su reforma y también es verdad que, en este caso, no puede formularse la crítica de que el Gobierno puede a través de un Reglamento, de forma independiente y no subordinada a la Ley, definir con completa libertad el tipo sino que, a mi parecer, el problema es otro distinto, no desde luego de jerarquía normativa sino el incriminar con-

29 SANTANA VEGA, D.M., El concepto de ley penal en blanco, ob. cit., págs. 46 y ss. 
ductas que ya son ilícitos administrativos sin establecer criterios de delimitación entre ambas infracciones, con la consiguiente remisión incondicionada y ciega del Código penal a la LOFPP, que supone criminalizar simples desobediencias administrativas mediante la protección de bienes jurídicos colectivos a través de delitos de peligro abstracto, a lo que cabe añadir un interrogante que no es intrascendente: si la descripción del comportamiento típico contiene el núcleo esencial de la prohibición ${ }^{30}$. Extremos que me llevan a mantener ciertas reservas sobre la constitucionalidad del actual art. 304 bis del Código penal.

Abundando en esta última misma cuestión y con el abierto propósito de polemizar, hemos hecho ya referencia a que la doctrina constitucional exige la concurrencia de una serie de requisitos para comprobar si el precepto penal cuestionado cumple con los requisitos exigibles a las leyes penales en blanco: a) que el reenvío normativo sea expreso y esté justificado en razón del bien jurídico protegido por la norma penal; b) que la ley, además de señalar la pena, contenga el núcleo esencial de la prohibición; y c), que sea satisfecha la exigencia de certeza, esto es, que "la conducta calificada de delictiva quede suficientemente precisada con el complemento indispensable de la norma a la que la ley penal se remite, y resulte de esta forma salvaguardada la función de garantía de tipo con la posibilidad de conocimiento de la actuación penalmente conminada" (entre otras muchas, STC $101 / 2012$, de 8 de mayo, FJ 5) ${ }^{31}$.

30 Al respecto, Vid., CÓRDOBA RODA, J., en Comentarios al Código penal. Parte General, (CÓRDOBA RODA-J.-GARCÍA ARÁN, M., directores), Madrid, 2011, pág. 16; GARCÍA ARÁN, M., "Remisiones normativas, leyes penales en blanco y estructura de la norma penal", ob. cit., pág. 89; HUERTA TOCILDO, S., "Principio de legalidad y normas sancionadoras", en El principio de legalidad. Actas de las V Jornadas de la asociación de Letrados del Tribunal Constitucional, ob. cit., págs. 21 y ss., quienes, en síntesis, entienden que no cabe discriminar entre el núcleo esencial y los elementos que forman el complemento, por la simple razón de que todos y cada uno de los elementos integrantes del tipo son imprescindibles para que éste concurra.

31 Vid, SANTANA VEGA, D.M., El concepto de ley penal en blanco, págs. 44 y ss. 
En primer lugar, es cierto que el reenvío normativo es expreso, si bien me suscita dudas su justificación en relación al bien jurídico protegido en la norma penal; pero además de ello creo que no es aventurado afirmar que la rúbrica del Título XIII bis se refiere a la conducta prohibida (la financiación ilegal de los partidos políticos), no al objeto de tutela ${ }^{32}$. Por otro lado, es indiscutible que la complejidad técnica de la materia y, seguramente, el hecho de que determinadas conductas a las que asiste un desvalor de acción innegable han quedado fuera del ámbito penal, por lo que no sería descartable una posterior acomodación normativa a la necesidad de incriminarlas que pondría en evidencia la necesidad de ampliar el tipo penal con, al menos, la remisión a otros preceptos de la LOFPP significaría una perturbación de la pretensión de permanencia de la norma penal en el tiempo.

En segundo lugar cabe preguntarse si la norma penal cuestionada contiene el núcleo esencial (o de la materia de prohibición), toda vez que remite íntegramente y sin ninguna precisión añadida la determinación de las conductas prohibidas al art. 5 LOFPP. Es cierto que al tratarse de una Ley Orgánica es el Parlamento quien define la conducta, pero también es verdad que es una norma administrativa la que dota de contenido al tipo, con la particularidad de que la norma de reenvío no contiene ninguna exigencia específica con respecto a la lesión o puesta en peligro del bien jurídico protegido (en realidad, aquí, conducta prohibida) que sirva para precisar el núcleo de la prohibición penal que, no olvidemos, lo determina una norma administrativa, con independencia del rango que posea.

En tercer lugar, parece que el art. 304 bis del Código penal, no satisface tampoco la exigencia de certeza a que obliga el principio de legalidad penal del art. 25.1 CE, ya que cuando se integra en el tipo la norma extrapenal (art. 5.Uno LOFPP),

32 MACIAS ESPEJO, B., "Sobre la incriminación de la financiación ilegal de partidos políticos en el artículo 304 bis del Código penal”, ob. cit., pág.127. 
no permite identificar con la necesaria y suficiente precisión la conducta que se tipifica.

Lo acabado de referir, esto es, la comprobación de si el precepto penal cuestionado cumple con los requisitos que el art. 25.1 CE exige al principio de legalidad, lo formulo como una reflexión absolutamente abierta realizada con el simple objeto de esbozar los elementos de discusión aunque, a la vez y manifestando mi posición al respecto, lo hasta ahora dicho me hace albergar dudas sobre la constitucionalidad de la actual tipificación del delito de financiación ilegal de los partidos políticos.

\subsection{Concurrencia normativa y bis in ídem}

Con carácter previo a abordar este espinoso tema me parece necesario realizar dos puntualizaciones que no por sabidas dejan de ser necesarias. En primer lugar, resulta que uno de los mayores problemas para delimitar la infracción administrativa de la infracción penal es la ausencia de diferencias esenciales entre ambos ilícitos cuando, como en este caso, no existen elementos que permitan diferenciarlos dado que el art. 304 bis del Código penal, para delimitar el contenido del injusto, remite en bloque a lo dispuesto en el art. 5.Uno de la LOFPP. En segundo lugar, no es tampoco ninguna novedad afirmar que no es posible incurrir en un ilícito penal por la mera infracción de un precepto administrativo, sino porque el comportamiento debe presentar un contenido material de antijuridicidad que ha de quedar plasmado en la afección al bien jurídico que la norma penal pretende proteger. Cuando ello no es así, creo que no es aventurado cuestionarse la oportunidad de la tipificación penal por los problemas de colisión o de concurrencia normativa ${ }^{33}$.

A este respecto, MAROTO CALATAYUD pone de relieve lo que denomina el "solapamiento exacto" entre la infracción prevista en el art. 5 LOFPP y el art. 304.bis 1 del Código penal lo cual, añade, puede vaciar de contenido la infracción del art. 5 LO-

33 SÁINZ-CANTERO CAPARRÓS, J.A., "Los delitos de financiación ilegal de los partidos políticos”, ob. cit., pág. 671. 
FPP, si bien, puntualiza, el sujeto activo de la citada ley son los partidos políticos, mientras que el Código penal se refiere al sujeto individual -sin perjuicio de lo previsto en el art. 304 bis. 5-. A su parecer, el nuevo tipo penal, en aquellos casos que quedarán fuera del alcance del referido art. 304 bis.5, podría impedir sancionar al partido si resulta preferente la vía penal ya que no se distingue si el proceso penal lo es contra persona física o jurídica ${ }^{34}$.

En una línea similar, OLAIZOLA NOGALES entiende que la situación es abiertamente insostenible dado que no se ofrece ningún elemento de diferenciación entre ambos ilícitos ${ }^{35}$; mientras que, SAÍNZ- CANTERO propone la adopción de criterios formales para solventar el conflicto. En efecto, atendiendo a lo previsto en el último punto del art. 17.Uno de la LOFPP ${ }^{36}$, señala que todos los hechos subsumibles en el art. 17.Dos a), en elación a lo previsto en el art. 5.Uno, serían constitutivos del delito del art. 304 bis. 1 del Código penal ${ }^{37}$. Una segunda opción interpretativa, también destacada por OLAIZOLA NOGALES ${ }^{38}$, sería la de atender a la literalidad del art. 17.Dos a), donde lo que se sanciona es "la aceptación de donaciones o aportaciones" (en lo que ahora nos interesa) que contravengan las limitaciones o

34 MAROTO CALATAYUD, M., "Financiación ilegal de partidos políticos" en Comentarios a la reforma penal de 2015, ob. cit. pág. 762.

35 OLAIZOLA NOGALES, I., "Las reformas legales relacionadas con la financiación de los partidos políticos", ob. cit., pág. 275. Igualmente, vid., BUSTOS RUBIO, M., "El nuevo delito de financiación ilegal de los partidos políticos", ob. cit., pág. 14

36 Artículo 17. Uno. "Sin perjuicio de las responsabilidades legales de cualquier índole que se deriven de lo dispuesto en el ordenamiento jurídico en general y de lo preceptuado en esta ley en particular, el Tribunal de Cuentas acordará la imposición de sanciones al partido político que cometa alguna de las infracciones que se tipifican en este artículo, siempre que no constituyan delito".

37 SÁINZ-CANTERO CAPARRÓS, J.E., "Los delitos de financiación ilegal de los partidos políticos", ob. cit., pág. 671

38 OLAIZOLA NOGALES, I., "Las reformas legales relacionadas con la financiación de los partidos políticos", ob. cit., pág. 275, quien propone la supresión del primer párrafo del art. 304 bis del Código penal y que la conducta del donante sea incluida como infracción administrativa. 
requisitos establecidos en el art. 5. Aceptación que, en este caso, sólo tiene efectos cuando la realiza el donatario, esto es, el partido político. Sin embargo, el art. 304 bis del Código penal sólo incrimina la conducta del que "reciba", que no ha de ser necesariamente el destinatario final de la donación o de la aportación, de modo que uno y otro precepto sancionan comportamientos distintos, evitando de esa forma la existencia de bis in ídem y estableciendo con ello un criterio de distinción entre ambos ilícitos, aunque, señala SÁINZ-CANTERO, sin que existan criterios que permitan justificar o entender el por qué no se sanciona penalmente la aceptación y sí la recepción de las donaciones o aportaciones ${ }^{39}$, cuando probablemente, me permito añadir, el desvalor de la conducta que viene presidida por la aceptación de la donación es de mayor entidad que la caracterizada por la simple recepción, que es la castigada en el Código penal ${ }^{40}$.

\subsection{Ubicación sistemática del Título XIII bis y objeto de tutela}

Al inicio ya referí que el nuevo Título XIII bis, arts. 304 bis y 304 ter, se incorporó al Código penal durante la tramitación parlamentaria de la L.O. 1/2015, de 30 de marzo, y que éste no figuraba en los textos iniciales del Anteproyecto ni del Proyecto de reforma del Código penal que, además, se encuentra sistemáticamente ubicado entre los Delitos contra el patrimonio y el orden socioeconómico (Título XIII y los Delitos contra la Hacienda Pública y la Seguridad Social (Título XIV), lo cual resulta difícilmente compatible con la Exposición de Motivos de la L.O. 1/2015, donde, el legislador, al explicitar las razones que motivaron su introducción en el Código penal se refiere a la necesidad de reforzar la punición de los "delitos contra la corrupción en el ámbito de la Administración pública". Como se

39 Íbidem.

40 Cfr., MACIAS ESPEJO, B., "Sobre la incriminación de la financiación ilegal de los partidos políticos en el art. 304 bis del Código penal”, ob. cit., pág. 133, quien, por el contario, entiende que el recibir supone disponibilidad material de la donación o de la aportación. 
puede advertir, la ceremonia de confusión está garantizada desde el inicio, cuando la rúbrica del Título se refiere a la conducta prohibida (la financiación ilegal de los partidos políticos) y no al objeto de tutela ${ }^{41} ; \mathrm{y}$, es más, la desorientación del legislador en relación a cuál es el bien jurídico protegido en estos delitos queda de manifiesto en la diversidad de opciones plasmadas, tanto en la fase de enmiendas como en la formulación final del comportamiento típico ${ }^{42}$. En todo caso, parece que el legislador, atendiendo a su ubicación, pretende dotar a este delito de un contenido patrimonial o de índole socio económico que no se compadece, ni con los fines, ni con las funciones de los partidos, ni con el correcto funcionamiento de la financiación del sistema de partidos políticos, distanciándose, así, de los delitos contra la corrupción en el ámbito de la Administración Pública a la que se refería en la Exposición de Motivos de la Reforma.

Entiendo que una de las premisas comúnmente aceptadas por la doctrina penal es que no puede legislarse a "golpe de telediario" para acallar indignaciones sociales o porque exista una preocupación en la ciudadanía a la que pretendidamente haya

41 MACIAS ESPEJO, B., "Sobre la incriminación de la financiación ilegal de partidos políticos en el art. 304 bis del Código penal”, ob. cit., pág. 127.

42 Vid., MAROTO CALATAYUD, M., La financiación ilegal de los partidos políticos. Un análisis político-criminal, ob. cit., págs. 309 y ss., donde se hace eco de las diversas propuestas. En síntesis, el Grupo Parlamentario UPyD propuso situarlo entre los delitos contra la administración pública, como un nuevo Capítulo XI del Título XIX, inmediatamente después de los delitos de corrupción en las transacciones internacionales; el Grupo Parlamentario Socialista la situó también en los arts. 304 bis y ss., pero en ese caso dentro del Título XIII (Delitos contra el patrimonio y el orden socioeconómico) creando un nuevo Capítulo XV; el Grupo Parlamentario Vasco, entre los delitos relativos al mercado y los consumidores como un subtipo del art. 286 bis, corrupción entre particulares; mientras que el representante de Compromís (Grupo Parlamentario Mixto) propuso introducirlos como arts. 422 bis y ter, entre los delitos contra la administración pública, pero vinculado al delito de cohecho y a la aceptación de regalos. Al respecto, vid., http://www.congreso.es/public_oficiales/L10/CONG/BOCG/A/ BOCG-10-A-66-2.PDF. Al respecto, igualmente, MACÍAS ESPEJO, B., "Sobre la incriminación de la financiación ilegal de partidos políticos en el artículo 304 bis el Código penal, ob. cit., pág. 128. 
que dar respuesta, sino que la criminalización de determinadas conductas debe de tener como presupuesto esencial el hecho de ser lesivas u ofensivas de un valor fundamental para la convivencia, debiendo descartarse la utilización del Derecho penal cuando no sea preciso por, entre otros, existir una tutela idónea en otros sectores del ordenamiento jurídico que sancionan esos mismos comportamientos ${ }^{43}$. Como ya se ha dicho, la decisión político criminal de incriminar el delito de financiación ilegal de los partidos políticos se había adoptado de forma "cautiva" ante los ingentes escándalos de corrupción vinculados a la financiación irregular de los partidos políticos que abarcaban una buena parte del arco parlamentario de nuestro país. El resultado de ello es la tipificación de determinados comportamientos, dejando extramuros del ámbito penal otros con un desvalor absolutamente similar, con el añadido de que la LOFPP sanciona, a su vez, los mismos comportamientos que castiga el Código penal.

Sea como fuere, lo que está al margen de cualquier discusión es, no sólo, el protagonismo que la Constitución atribuye a los partidos políticos, ya no únicamente como mecanismo para la expresión del pluralismo político, sino como instrumentos que concurren a la formación y manifestación de la voluntad popular, además de atribuirles la condición de instrumento fundamental para la participación política, a lo que debe añadirse el mandato de que "su estructura interna y funcionamiento deberán ser democráticos". Es más, la especial condición constitucional que el art. $6 \mathrm{CE}$ confiere a los partidos políticos impide que puedan considerarse simples personas jurídico-privadas titulares del derecho de asociación contemplado en el art. $22 \mathrm{CE}$, un claro ejemplo de ello es que los partidos políticos se hallan sometidos a la Ley de Contratos de la Administración Pública ${ }^{44}$,

43 SAINZ-CANTERO CAPARRÓS, J.E., "Los delitos de financiación ilegal de partidos políticos”, ob. cit., pág. 662. Asimismo, vid., NÚÑEZ CASTAÑO, E., "La cuestionable regulación penal de los delitos de financiación ilegal de partidos políticos", ob. cit., pág. 132.

$44 \mathrm{Al}$ respecto vid, Real Decreto Legislativo 3/2011, de 14 de noviembre, por el que se aprueba el texto refundido de la Ley de Contratos del Sector Público. 
lo que tan sólo se explica si éstos trascienden la esfera estrictamente privada. Por ello, "los arts. 6 y 22 deben interpretarse conjunta y sistemáticamente, sin separaciones artificiosas y, en consecuencia, debe reconocerse que el principio de organización y funcionamiento interno democrático y los derechos que de él derivan integran el contenido del derecho de asociación cuando éste opera sobre la variante asociativa de los partidos políticos" (STC 56/1995, FJ 3), principio que se articula como uno de los parámetros de la L.O. 6/2007, de 27 de junio, de partidos políticos, donde su art. 6 prescribe que la organización, funcionamiento y actividad de los partidos se ajustarán a los principios democráticos así como a lo dispuesto en las leyes y en la Constitución, si bien ahora se complementa con la afirmación, en positivo, de la capacidad organizativa y funcional de los partidos y la consiguiente necesidad de respetarla: "Los partidos políticos se ajustarán en su organización, funcionamiento y actividad a los principios democráticos y a lo dispuesto en la Constitución y en las leyes", cuya razón de ser se manifiesta en la exigencia constitucional de que su estructura y funcionamiento han de ser democráticos, lo que se traduce en el reconocimiento del derecho de los afiliados a la participación en su organización y funcionamiento (STC 226/2016, de 22 de diciembre, FJ 6).

Una vez perfilado el escenario general, es inevitable convenir que el objeto de tutela en estos delitos es absolutamente poliédrico, así se ha manifestado la doctrina en función de cuál ha sido el ámbito de protección al que, entienden, se le ha de dispensar mayor intensidad. No obstante, una buena parte de las propuestas abundan en las funciones constitucionales atribuidas a los partidos políticos, sin desconocer que las prácticas de financiación ilegal suelen encuadrarse en un ámbito muy próximo a los delitos contra la Administración Pública y, en particular, al cohecho, la malversación de caudales públicos, la prevaricación, el tráfico de influencias o, incluso, los fraudes a la Administración Pública ${ }^{45}$. En una línea complementaria a las anteriores,

45 MAROTO CALATAYUD, M., "Financiación ilegal de partidos políticos", ob. cit., pág. 761 . 
MUÑOZ CONDE lo considera un delito contra el orden constitucional, cuyo correcto funcionamiento depende de que los partidos políticos ejerzan en condiciones de igualdad y garanticen el pluralismo político, a lo que puntualiza que también puede considerarse como un delito contra la administración pública principalmente como un cohecho que, a su vez, puede dar lugar a delitos de otra naturaleza ya que el sujeto activo de tal comportamiento, el dirigente de un partido político, en muchas ocasiones ostenta la condición de autoridad o de funcionario público ${ }^{46}$.

Por su parte, OLAIZOLA NOGALES considera que los partidos políticos cumplen una función básica para el funcionamiento democrático del Estado. A su parecer, son expresiones de pluralismo político e instrumentos fundamentales de participación política: los partidos son los intermediarios entre la sociedad y el Estado, por lo que esa manifestación de la voluntad popular es lo que debe producirse libre de injerencias extrañas que busquen favorecer intereses y voluntades frente a voluntades programáticas. Añade que la formación y manifestación de la voluntad popular precisan de democracia interna dentro del partido y de transparencia, aunque ninguno de ellos tiene entidad en sí misma como para ser reconocido como un bien jurídico penal. En cuanto a la democracia interna, sin perjuicio de que cuanto menor sea la democracia interna más alto será el riesgo de clientelismo, considera que la perturbación de los procesos internos de los partidos no tiene entidad suficiente para constituir un injusto específico, por ello sólo se sancionarán penalmente aquellas conductas que, trascendiendo del ámbito interno del partido,

46 MUÑOZ CONDE, F., Derecho Penal. Parte Especial, 20 a edición, Valencia, 2015, pág. 475. En el mismo sentido, Vid., JAVATO MARTÍN, A., en Comentarios Prácticos al Código Penal (GÓMEZ TOMILlO, M., director), $3^{\text {a }}$ edición, Pamplona, 2016, pág. 719, quien afirma: "no se puede desconocer su vinculación con otros delitos contra la Administración pública; de tal manera que su tipificación podría responder, en parte, al peligro de comisión de un delito contra la Administración Pública, peligro que parece especialmente patente en caso de una entrega finalista o revocable". 
supongan una perturbación manifiesta de la voluntad popular. En relación a la transparencia señala que la razón por la que la norma administrativa prohíbe las donaciones anónimas, es para evitar que los partidos políticos puedan favorecer los intereses privados de los donantes. Es más, continúa, si lo protegible fuera la transparencia no habría límites cuantitativos o no se prohibirían las donaciones provenientes de empresas contratadas por la Administración ya que sería suficiente, para proteger la trasparencia, que el ciudadano pudiera conocerlo. Concluyendo que para que el derecho penal intervenga "será preciso que se constate al menos un peligro cercano de favorecimiento de intereses particulares, en detrimento de la voluntad programática y/o popular" ${ }^{47}$ En todo caso, el correcto funcionamiento del sistema de partidos no constituye en sí mismo un bien jurídico merecedor de protección penal, sino que para decidir si una conducta es merecedora de reproche penal y cuándo no, se ha de derivar de las funciones constitucionales que ejercen los partidos políticos y que se explicitan en el art. $6 \mathrm{CE}$ : expresan el pluralismo político, concurren a la formación y manifestación de la voluntad popular y son instrumentos esenciales para la participación política ${ }^{48}$.

Asimismo, NIETO MARTÍN se ha mostrado partidario de la tipificación autónoma del delito de financiación ilegal de partidos políticos, quien sin dejar de considerar que en muchos casos la financiación ilícita del partido se hace a cambio de una contrapartida, con lo cual cohecho y financiación ilegal vendrían a solaparse, lo cierto - continúa- es que dada la independencia de los bienes jurídicos y el mayor contenido del injusto, el problema se debe solucionar a través de la vía del concurso de delitos. Así, si con el delito de cohecho se tutela la "sumisión" de

47 OLAIZOLA NOGALES, I., "Las reformas legales relacionadas con la financiación de los partidos políticos", ob. cit., págs. 267, 271. Igualmente, de la mima autora, La financiación ilegal de los partidos políticos: un foco de corrupción, ob. cit., págs. 203 y ss.

48 OLAIZOLA NOGALES, I., "El delito de financiación ilegal de partidos políticos en la reforma del CP”, en Diario La Ley, $\mathrm{n}^{\circ}$ 8516, 10 de abril de 2015, Ref. D-141, pág. 2. 
la administración al principio de legalidad, con la financiación ilegal se tutela la igualdad de oportunidades entre las distintas fuerzas políticas como la transparencia patrimonial en la financiación del partido ${ }^{49}$. A lo que puntualiza que la financiación ilegal de los partidos políticos lesiona bienes jurídicos penales autónomos de extraordinaria importancia para el sistema democrático, como la transparencia en la financiación, la igualdad de oportunidades entre las distintas fuerzas políticas y la democracia interna dentro de los partidos políticos ${ }^{50}$.

Con carácter inmediatamente anterior a la tipificación del delito, MAROTO CALATAYUD identificaba tres bloques de bienes jurídicos en los delitos de corrupción, entendida en sentido amplio, donde incluía tanto a la corrupción pública como a la privada. Así, distinguía:

a. Bienes jurídicos colectivos relacionados con las funciones constitucionales atribuidas a distintas instituciones del ordenamiento jurídico, en particular la administración pública pero sin descartar otras como, por ejemplo, el mercado. Por ello, señala, el injusto se identifica con bienes jurídicos colectivos asociados a finalidades esenciales del Estado ${ }^{51}$.

b. Bienes jurídicos vinculados al elemento patrimonial o socioeconómico, público o privado, en los que el núcleo común que constituye la acción típica son las disposiciones patrimoniales ${ }^{52}$.

c. Tipos de organización criminal y criminalidad organizada ${ }^{53}$ que, a su parecer, responden a una lógica más

49 NIETO MARTÍN, A., "Financiación ilegal de partidos políticos (arts. 1013)", en Fraude y corrupción en el Derecho penal económico europeo. Eurodelitos de corrupción y fraude, Cuenca, 2006, pág. 123.

50 NIETO MARTÍN, A., ob. cit., p. 123.

51 MAROTO CALATAYUD, M., La financiación ilegal de los partidos políticos. Un análisis político-criminal, ob. cit., págs. 185-186.

52 MAROTO CALATAYUD, M., ob. cit., pág. 186.

53 Al respecto, Vid., el reciente trabajo de LEÓN ALAPONT, J., "La responsabilidad penal de los partidos políticos en España. ¿Disfuncionalidad normativa?, en Revista General de Derecho Penal, n² 27, 2017, passim. 
policial que dogmática y que los convierte en particularmente útiles como delitos accesorios, lo cual no ha sido obstáculo para que uno de los tipos de financiación ilegal introducidos haya sido uno de organización ilegal, art. 304 ter $^{54}$.

Llegados a este punto me gustaría hacer dos puntualizaciones. En primer lugar, como muy bien sostiene NAVARRO CARDOSO $^{55}$, creo que hay que descartar concepciones patrimonialistas, de tipo económico o de carácter individual en relación al bien jurídico protegido en estos delitos, ya que parece más razonable atender a conceptos de otra índole en relación con las funciones atribuidas constitucionalmente al sistema de partidos, sin perjuicio de que como consecuencia de estas conductas pueda ocasionarse alguna afección puntual a bienes jurídicos de carácter individual ${ }^{56}$.

En segundo lugar, en relación con la propuesta realizada por OLAIZOLA NOGALES y las dudas que suscita al excluir del ámbito típico los procesos internos de los partidos que, como refiere la citada autora, "no tienen entidad suficiente para constituir un injusto específico". Comportamientos que permanecen en el ámbito interno de la organización del partido político sin una manifiesta trascendencia al exterior, es decir, la democracia interna en sí misma "no tiene entidad para ser reconocida como un bien jurídico penal, al menos autónomo" ${ }^{57}$, se trata de una propuesta que, a mi parecer, se saca de contexto. Vaya por adelantado que no se puede negar que el art. $6 \mathrm{CE}$ hace una mención expresa a que: "su estructura interna y funcionamiento deberán ser democráticos", como así lo establece también el art. 7 de la

\section{4 Íbidem.}

55 NAVARRO CARDOSO, F., "Corrupción, transparencia y Derecho penal. Especial referencia al Derecho de acceso a la información pública", en Cuadernos de Política Criminal, n 114, 2014, págs. 104-105.

56 En el mismo sentido, Vid., BUSTOS RUBIO, M., "El nuevo delito de financiación ilegal de partidos políticos", ob. cit., pág. 7.

57 OLAIZOLA NOGALES, I., La financiación ilegal de los partidos políticos: un foco de corrupción, ob. cit., pág. 206. 
L.O. 6/2002, de 27 de junio, de Partidos Políticos; y, creo que está fuera de cualquier duda la trascendencia que tiene la democracia interna de los partidos que, sin ir más lejos, se prevé expresamente en el Capítulo II de la L.O. 6/2002, arts. 6 y ss, con referencias expresas al establecimiento de fórmulas de participación directa de los afiliados "... especialmente en los procesos de elección de órgano superior de gobierno del partido". Ahora bien, sin que ello suponga poner en tela de juicio, ni cuestionar la trascendencia de un sistema democrático interno de un partido político que, desde luego, respete el pluralismo ideológico en la organización, las distintas sensibilidades que la integran, la elección de los miembros de la dirección, etc., la pregunta que cabe inferir de lo anterior es: ¿en qué condiciona la democracia interna de los partidos el comportamiento típico dispuesto en el art. 304 bis del Código penal? Creo que, sin minusvalorar el funcionamiento interno democrático de un partido político, el hecho de que se produzcan irregularidades en esos procesos de funcionamiento interno, no implica que necesariamente se incurra en un delito de financiación ilegal de partidos políticos ${ }^{58}$.

Ahora bien, nótese que a lo largo de estas páginas y, desde luego, al tomar como referencia la rúbrica del Título XIII bis del Código penal, hemos utilizado genéricamente la fórmula "financiación ilegal" de los partidos políticos. Sin embargo, llegados a este punto creo que es necesario introducir una caracterización específica entre las diversas modalidades de financiación ilícita de partidos políticos ${ }^{59}$. Así, MALEM diferencia entre financiación irregular, financiación ilegal y financiación corrupta

58 Cfr., de otra opinión, BUSTOS RUBIO, M., "El nuevo delito de financiación ilegal de partidos políticos", ob. cit., pág. 8; NUÑEZ CASTAÑO, E., "La cuestionable regulación penal de los delitos de financiación ilegal de partidos políticos", ob. cit., págs. 132-133.

59 Al respecto, Vid., MAROTO CALATAYUD, M., La financiación ilegal de los partidos políticos. Un análisis político-criminal, ob. cit., págs. 181-182 donde trae a colación otras propuestas más casuísticas de corrupción y financiación ilícita de partidos políticos. 
de los partidos políticos ${ }^{60}$. Clasificación, señala el citado autor, que puede ser útil para comprender ciertas estrategias de financiación utilizadas por los partidos con el argumento de que no trasgreden ninguna ley. Así, la financiación irregular vendría presidida por la utilización de los espacios o vacíos dejados por la leyes para conseguir una financiación del partido político a través de un "recorrido no prohibido por norma alguna" ${ }^{1}$, que podría ser una financiación ilegal obtenida mediante fraude de ${ }^{l e y}{ }^{62}$. Por otro lado, la financiación ilegal sería aquella donde, a diferencia de la anterior, el partido vulnera alguna de las prohibiciones en la materia, esto es, sería aquella expresamente prohibida por el Derecho y que podría consistir tanto en una infracción penal como administrativa. Sería el caso, apunta MALEM, en el que se excede el monto de una donación o se distraen fondos destinados a fines permitidos para destinarlos a otras actividades prohibidas legalmente ${ }^{63}$. Y, finalmente, la financiación corrupta, sería el caso de quien recibe los fondos en nombre del partido y se compromete a tomar una decisión o que otros la adopten en el sentido deseado por el donante. Se trata, en definitiva, una conducta que viene presidida por la "venta" de una decisión política a cambio de dinero ${ }^{64}$.

60 MALEM SEÑA J.F., La corrupción. Aspectos éticos, económicos, politicos y jurídicos, Barcelona, 2002, págs. 109 y ss. Asimismo, Vid., SANDOVAL, J.C. "Aportación a una reflexión político criminal sobre la corrupción en la financiación de los partidos políticos", en Revista General de Derecho Penal, $\mathrm{n}^{\circ} 22,2014$, pág. 2 y ss.

61 MALEM SEÑA J.F., La corrupción, ob. cit., pág. 113. Es muy ilustrativo uno de los ejemplos con el que ilustra este tipo de actividades. Así, en el caso de Francia, explica que: “...para evitar las restricciones legales a las donaciones a las agrupaciones políticas, los partidos tomaron la decisión de insertar propaganda en sus revistas y publicaciones, supuesto no vedado por la ley".

62 Cfr., SANDOVAL, J.C., ob. cit., pág. 41, quien entiende que se trata de conductas que no pueden ser sancionadas por el ordenamiento jurídico, puesto que están autorizadas.

63 MALEM SEÑA J.F, ob. cit., pág. 114.

64 Íbidem. 
Comportamientos que, en suma, no siempre será sencillo diferenciar pero que es necesario precisar para delimitar cuáles de esas conductas de financiación ilícita merecen un mayor reproche penal como consecuencia de la mayor entidad del desvalor del comportamiento ${ }^{65}$, lo cual nos lleva a distinguir entre responsabilidad moral, política o jurídica con la particularidad de que no toda la financiación ilícita es constitutiva de delito. Esto es, entre un comportamiento reprobable ética y políticamente, de un comportamiento merecedor de una sanción administrativa o de una conducta merecedora de sanción penal.

A mi parecer la clarificación conceptual propuesta por MALEM nos ayuda a perfilar determinados actos que, genéricamente, se denominan "corrupción" de aquellos que en puridad serían comportamientos propios de financiación ilícita de partidos políticos. Llegados a este punto me parece oportuno volver a traer a escena una discusión a la que he hecho referencia con anterioridad. Me refiero a si la falta de democracia interna de los partidos es merecedora de protección penal como señalan algunos autores, por tratarse de uno de los aspectos inherentes al buen funcionamiento de aquéllos y, en ese caso, su relación con la financiación ilícita de los partidos políticos ${ }^{66}$. A mi entender se trata de dos cuestiones que es necesario diferenciar dado que, aunque pueda establecerse algún vínculo entre ambas y puedan llegar a converger, son esferas distintas. Una es la financiación ilícita de los partidos políticos, mientras que la otra, relativa la falta de democracia interna, podría enmarcarse dentro de lo que podría denominarse corrupción política.

65 SANDOVAL, J.C. "Aportación a una reflexión político criminal sobre la corrupción en la financiación de los partidos políticos", ob. cit., págs. 17 y ss., quien se refiere a "financiación anómala" para englobar a la financiación ilícita, a la financiación irregular y a la financiación corrupta.

66 BUSTOS RUBIO, M., "El nuevo delito de financiación ilegal de partidos políticos", ob. cit., pág. 8; NUÑEZ CASTANO, E., "La cuestionable regulación penal de los delitos de financiación ilegal de partidos políticos", $o b$. cit., págs. 133-134. 
Es evidente que conceptuar la corrupción política excede con creces el propósito de este trabajo pero sí podríamos utilizar una fórmula que nos aproxime, aunque sin dejar de admitir que las definiciones en este ámbito tienen un carácter particularmente amplio. Así, el Informe sobre la lucha contra la corrupción en la UE, elaborado por la Comisión Europea, la conceptualiza como "cualquier abuso de poder para obtener réditos privados" ${ }^{\prime 67}$. En términos similares se pronuncia la OCDE al conceptuar la corrupción como "el abuso de poder que le ha sido confiado a un determinado agente para obtener ganancias privadas" ${ }^{\prime \prime 8}$. Aún y siendo consciente, insisto, de la amplitud del concepto lo que me parece indudable, como sostiene SANDOVAL, es que la corrupción pública no es una categoría conceptual útil para el estudio de la financiación política corrupta ${ }^{69}$.

Una vez introducidas las matizaciones anteriores es el momento de precisar el bien jurídico protegido en estos delitos. A mi juicio, debe interpretarse atendiendo a las funciones que atribuye la Constitución a los partidos políticos en su art. 6, esto es, en el condicionamiento y/o alteración de esas funciones. Creo que no es aventurado afirmar que el pluralismo político resulta seriamente amenazado cuando en una contienda electoral concurren otros partidos en condiciones de desigualdad al sufragar su campaña con una financiación adicional e ilícita, lo que en una innegable relación de causalidad condiciona una mediatizada voluntad popular. Como muy bien señala SAINZ -CANTERO ${ }^{70}$, en un sistema electoral como el nuestro -donde el marketing político, la mayor presencia en los medios de comunicación o las campañas electorales que disponen de más financiación- hace que algunos partan en una clara situación de

67 Al respecto, vid., SANDOVAL, J.C. "Aportación a una reflexión político criminal sobre la corrupción en la financiación de los partidos políticos”, $o b$. cit., págs. 10

68 SANDOVAL, J.C., ob. cit., nota a pie de página núm. 35

69 Íbidem., pág. 12.

70 SAINZ-CANTERO CAPARRÓS, J.E., "Los delitos de financiación ilegal de partidos políticos”, ob. cit., pág. 665 . 
desigualdad con respecto al resto de partidos. Añadámosle a lo anterior -de nuevo posibilitado por la mayor disponibilidad económica- la creciente presencia en las nuevas tecnologías o la utilización de influyentes instrumentos virtuales que son capaces de crear opinión en determinados sectores, todo ello tiene como consecuencia que se afronte la contienda electoral en franco desequilibrio.

En directa relación con lo anterior, la alteración del pluralismo político y el condicionamiento de la formación y manifestación de la voluntad popular, como consecuencia de la financiación ilícita de un partido político, tiene como efecto inmediato la adulteración de la participación política a través de los partidos. En efecto, el art. 6 de la CE atribuye a los partidos el carácter de instrumento fundamental para la participación política, pero ese instrumento resulta objetivamente subordinado a su financiación ya que al disponer de mayores ingresos les permite disponer de una mayor representación y con ello una sólida presencia en los órganos y poderes del Estado, lo cual supone una clara quiebra de los principios de igualdad, objetividad $\mathrm{y}$ transparencia en el funcionamiento de una de las estructuras fundamentales del Estado ${ }^{71}$.

\subsection{Las puertas continúan abiertas: atipicidades}

Más allá de las opiniones de los autores que consideran saludable la incorporación de estos delitos al Código penal ${ }^{72}$, es incuestionable que existen conductas que se han situado extramuros del Derecho penal y que, en su caso, sólo serán merecedores de sanción administrativa a pesar de que el desvalor del comportamiento sea, en ocasiones, análogo o superior a los, en este momento, penalmente típicos. En esa línea de consideracio-

71 MACÍAS ESPEJO, B., "Sobre la incriminación de la financiación ilegal de partidos políticos en el artículo 304 bis del Código penal", ob. cit., pág. 131. Asimismo, SAINZ-CANTERO CAPARRÓS, J.E., "Los delitos de financiación ilegal de partidos políticos", ob. cit., pág. 666.

72 MUÑOZ CUESTA, F.J., "Delitos de financiación ilegal de partidos políticos", ob. cit., pág. 1. 
nes, en mi opinión es sorprendente que el ilícito se circunscriba a la financiación de origen privado para el funcionamiento habitual de los partidos, que se quede fuera la financiación de origen público, o que resulten penalmente irrelevantes la financiación ilícita destinada a gasto electoral o, tan grave como lo anterior, que se descarte a las fundaciones del ámbito de aplicación de la LOFPP y, lamentablemente, del Código penal ${ }^{73}$.

Vaya por adelantado que no realizaré un análisis detallado de las atipicidades que se desprenden de la regulación actual de estos delitos sino que, únicamente, me detendré en alguna de las, llamémosle así, "incongruencias legislativas". Esto es, en algunas de las que van más allá de las infracciones previstas en el art. 5. Uno (límites a las donaciones privadas) y art. 7.Dos (aportaciones de personas extranjeras) de la L.O. 8/2007, de 4 de julio, LOFPP.

a) Las llaves del castillo: la financiación de los partidos políticos a través de las fundaciones

El art. 1 LOFPP determina el ámbito de aplicación de la ley, que se hace extensiva no sólo a los partidos políticos sino, también, a las coaliciones, federaciones o agrupaciones de electores. A este respecto, quisiera llamar la atención de que en el articulado no se hace mención alguna a las fundaciones, a excepción de lo dispuesto en la Disposición adicional séptima, dilatadísima y ardua previsión que regula los requisitos que deben concurrir para estimar que una fundación está vinculada o es dependiente de un partido político.

Ahora bien, lo que me parece muy significativo son los apartados cuatro y cinco de la Disposición adicional. En el primero de ellos se excepciona a las fundaciones del tipo penal. Así, si bien prevé que en el caso de las donaciones las funda-

73 PUENTE ABA, L.M., "Financiación ilegal de partidos políticos (art. 304 bis CP)", en Comentarios a la reforma del Código penal de 2015, ob. cit., pág. 1066. Igualmente, vid., BUSTOS RUBIO, M., "El nuevo delito de financiación ilegal de partidos políticos", ob. cit., pág. 11. 
ciones estarán condicionadas a los límites y requisitos previstos en el capítulo segundo del Título II de la Ley (Fuentes de financiación), seguidamente recoge que no les es aplicable lo dispuesto en el art. 5.Uno, letras b) y c); en otras palabras: no tendrán prohibido aceptar o recibir donaciones con origen en personas jurídicas así como de entes sin personalidad jurídica. No obstante, cuando esas donaciones sean de carácter económico y superiores a 120.000 euros deberán formalizarlas en documento público. No es eso todo, no se les prohíbe aceptar o recibir donaciones provenientes de una misma persona superiores a 50.000 euros anuales.

Asimismo, resulta de interés otro dato que no es menor: la financiación de los partidos políticos mediante las fundaciones se flexibiliza aún más en el apartado siguiente de la Disposición adicional séptima, puesto que descartan como donaciones las entregas monetarias o patrimoniales realizadas por una persona física o jurídica para "financiar una actividad o un proyecto concreto de la fundación o entidad". Es decir, no se instaura ningún límite o control para la aportación de entregas monetarias o patrimoniales sino que únicamente se exige su formalización en documento público, además de la obligatoriedad de comunicarlas al Tribunal de Cuentas en un plazo máximo de tres meses. A este respecto, GÓMEZ BENÍTEZ pone de manifiesto que no es infrecuente que los convenios suscritos entre partidos políticos y fundaciones oculten auténticas donaciones realizadas al margen de la LOFPP y de la L.O. 50/2002, de 26 de diciembre, de Fundaciones, donde se estipula que han de destinar el $70 \%$ de sus ingresos a los fines fundacionales y el resto a reserva o incremento de la dotación ${ }^{74}$, "en ningún caso a financiar de forma

74 Art. 27.1 L.O. 50/2002, de 26 de diciembre, Destino de rentas e ingresos: "A la realización de los fines fundacionales deberá ser destinado, al menos, el 70 por 100 de los resultados de las explotaciones económicas que se desarrollen y de los ingresos que se obtengan por cualquier otro concepto, deducidos los gastos realizados, para la obtención de tales resultados o ingresos, debiendo destinar el resto a incrementar bien la dotación o bien las reservas según acuerdo del Patronato..." 
camuflada a los partidos de los que dependen y sus campañas electorales" $" 75$.

Creo que no es aventurado afirmar que la inexistencia de límites cuantitativos para la financiación de las fundaciones deviene en un insalvable obstáculo para garantizar la transparencia y la limitación de la financiación de los partidos políticos. Permítaseme decirlo de otra manera: a pesar de que el legislador pretenda solventar las vías de financiación paralela que permite la LOFPP, si no se aplica a las fundaciones el mismo régimen de prohibiciones a los que somete a los partidos políticos para evitar la financiación ilícita, el sistema continuará siendo estructuralmente ineficaz ${ }^{76}$. A pesar de todo, creo que no es ocioso recordar que el Tribunal Supremo entiende que a las fundaciones les es aplicable la teoría del levantamiento del velo, por lo que si éstas no destinan su patrimonio al cumplimiento de sus fines y devienen en una mera "tapadera" para la financiación de los partidos políticos, no existen problemas para aplicar el tipo penal correspondiente, sin perjuicio de los problemas de prueba que se pudieran suscitar para acreditar esa circunstancia ${ }^{77}$.

75 GÓMEZ BENÍTEZ, J.M., Financiación ilegal de partidos políticos y corrupción", ob. cit., pág. 148.

76 Vid al respecto http://www.elmundo.es/espana/2017/06/07/593816cce2704e3 e378b45d0.html donde entre otras cosas se dice lo siguiente: «....Las fundaciones y entidades vinculadas a partidos políticos tienen prohibido asumir gastos que corresponden a estas fuerzas. Sin embargo, como ha reconocido el presidente del Tribunal de Cuentas, "en la medida en que éstas pueden hacer aportaciones a los partidos se produce un corte en la secuencia de control porque los partidos reciben fondos que no deberían”. Para evitar esta financiación de los partidos al margen de la ley, Ramón Álvarez de Miranda, que ha calificado este asuntos como una de las "mayores preocupaciones" del tribunal, ha pedido una reforma legal que amplíe sus competencias fiscalizadoras, pues se ha quejado de que éstas están limitadas a la regularidad de las aportaciones que reciben y a los gastos financiados con subvenciones públicas. El Tribunal de Cuentas reconoce el uso de las fundaciones y entidades vinculadas a partidos "para la captación de recursos destinados a las formaciones", y ha pedido que se apliquen a las fundaciones los mismos requisitos y limitaciones que se exigen a los partidos en materia de donaciones».

77 Vid., el art. 3.3. de la Ley 50/2002, de 26 de diciembre, de Fundaciones, donde, refiriéndose a sus fines y beneficios, expresamente se dispone: "En 


\section{b) Un nuevo elemento de distorsión: la condonación de}

la deuda.

Si la situación descrita en el apartado anterior es sorprendente por las vías paralelas de financiación que se posibilitan a través de las fundaciones, lo relativo a la condonación de la deuda de los partidos políticos por parte de algunas entidades bancarias es, atendiendo a los antecedentes, "inexplicable" En efecto, la L.O. 3/2015, de 30 de marzo, de control de la actividad económico financiera de los partidos políticos, introdujo en el art. 4.Cuatro de la LOFPP un mecanismo que pretendía evitar una práctica que no es infrecuente entre las entidades de crédito y los partidos políticos: la prohibición de las condonaciones totales o parciales de la deuda, así como la prohibición de establecer condiciones ventajosas en los créditos otorgados a los partidos como, por ejemplo, un tipo de interés de la deuda que fuere inferior al de las condiciones de mercado. En todo caso, la condonación de la deuda es un comportamiento que el art. 17.Dos a) estipula como infracción muy grave, a la que le corresponde una sanción que, en ningún caso, será inferior a las 50.000 euros y que, asimismo, podría alcanzar una importe que fuere del doble al quíntuplo de la cantidad condonada.

ningún caso podrán constituirse fundaciones con la finalidad principal de destinar sus prestaciones al fundador o a los patronos, a sus cónyuges o personas ligadas con análoga relación de afectividad, o a sus parientes hasta el cuarto grado inclusive, así como a personas jurídicas singularizadas que no persigan fines de interés general. Al respecto, vid., DE ÁNGEL YÁGÚEZ, R., La doctrina del levantamiento del velo de la persona jurídica en la jurisprudencia, $6^{\mathrm{a}}$ edición, Pamplona, 2013, págs. 482 y ss., 953 y ss. 1169 y ss.

78 Al respecto, http://www.20minutos.es/noticia/1699362/0/financiacion-ilegal/unio/pallerols/, donde se afirma: “...En noviembre de 2005 se supo que el PSC (Partido de los Socialistas de Cataluña, asociado al PSOE) había conseguido que La Caixa le condonara el $45 \%$ de la deuda vencida que arrastraba desde 1994. En total, se trataba de 6,57 millones de euros perdonados. El resto (7,81 millones) fue renegociado, con un tipo de interés tres veces inferior al aplicable en 1994...". 
Como es fácilmente imaginable, es una previsión severamente criticada por la doctrina penal ${ }^{79}$, no por el hecho de que se haya integrado esa infracción a la LOFPP, sino porque deviene penalmente atípica puesto que las únicas previsiones elevadas a la categoría de delito, como es bien conocido, son las de los arts. 5. Uno y 7.Dos de la L.O.8/2007, de 4 de julio. No obstante, quisiera enfatizar que ello no significa que esas conductas devinieran impunes ya que, perfectamente, podrían constituir un delito de administración desleal por parte del donante al disponer ilícitamente del patrimonio del administrado ${ }^{80}$.

\section{c) ¿Alguien da más?: las operaciones asimiladas}

El hecho de que un tercero asuma gastos de un partido político (bienes, obras o servicios o de cualquiera otros gastos que genere su actividad), se prevé en el art. 4.Tres de la LOFPP con la denominación de "operaciones asimiladas". Se trata de un comportamiento constitutivo de una infracción administrativa muy grave del art. 17.Dos a), a la que le corresponde una sanción cuyo importe irá del doble al quíntuplo de la cantidad asumida por el tercero y que, como se mencionó, un partido político fue condenado como partícipe a título lucrativo (asunto Pallerols) por el pago de material de oficina e informática para las sedes del partido, así como por el pago de algunas nóminas de sus empleados ${ }^{81}$. Creo que no se puede desdeñar la trascendencia de un comportamiento de esas característica de, en suma,

79 Por todos, vid., MACÍAS ESPEJO, B., "Sobre la incriminación de la financiación ilegal de partidos políticos en el artículo 304 bis del Código penal", ob. cit., pág. 134, nota a pie de página núm. 46, donde refiere a una parte de los autores que se muestran críticos con el restringido perfil del tipo.

80 GÓMEZ BENÍTEZ, J.M., "Financiación ilegal de partidos políticos y corrupción", ob. cit., pág. 150; MACIAS ESPEJO, B. "Sobre la incriminación de la financiación ilegal de partidos políticos en el artículo 304 bis del Código penal", ob. cit., pág. 141.

81 Vid. SAP Barcelona (Sección 2a ), de 21 de enero de 2013, folios 49 y ss. donde detalla las cantidades (un total de 388.000 euros) y las partidas de las que se benefició Unió Democrática de Catalunya. 
del desvalor de la conducta. A pesar de ello, se trata de una infracción que para el legislador carece de relevancia penal y, en consecuencia, es penalmente atípica. inmuebles

d) Un absurdo indescifrable: las donaciones de bienes

Se trata de una (otra) de las previsiones que corrobora la mejorable formulación del comportamiento típico de este delito. Así, en el art. 4.Dos e) LOFPP se dispone que las donaciones en especie se entenderán aceptadas por la simple certificación expedida por el partido político, donde constará la identificación del donante, el documento que acredite la entrega del bien donado así como su carácter irrevocable.

Una donación privada a un partido político que, como es habitual, está supeditada a los límites que se establecen en el art. 5.Uno b) LOFPP, esto es, no pueden exceder de 50.000 euros anuales y, por ello, tal como prevé el art. 304 bis del Código penal, lo que vaya más allá de esa cantidad será constitutivo de delito.

Ahora bien, en el último apartado del art. 5.Uno se excepciona esa previsión al excluir el límite previsto en la letra b) para las donaciones en especie de bienes inmuebles siempre que se cumplan los requisitos de aceptación expresa, conste la identidad del donante, así como el carácter irrevocable de la donación. En otras palabras, los partidos políticos pueden ser destinatarios de donaciones de inmuebles de valor ilimitado.

\section{ilicita}

e) Siempre se puede empeorar: la financiación pública

Uno de los supuestos de atipicidad penal que me parece inexplicable es el que tiene su origen en la financiación pública ilícita, por lo que es inevitable preguntarse o cuestionarse por las razones del legislador para dejar fuera del ámbito típico del art. 304 bis del Código penal las subvenciones públicas de carácter ilícito. 
En el art. 2.Uno de la LOFPP se pormenorizan los recursos económicos con origen en la financiación pública que se destinan a los partidos políticos ${ }^{82}$. Por su parte, el art. 3 regula las condiciones para la concesión de esas subvenciones que, no es precipitado afirmar, pueden realizarse forma ilícita. No obstante, me resulta sorprendente que el régimen sancionador establecido en la LOFPP, arts. 17 y ss. no contemple ninguna mención a las infracciones en las que pudiera incurrir la Administración por el hecho de otorgar una subvención pública ilícita a excepción, eso sí, de la cláusula general del art. 17.Uno ${ }^{83}$. Si a ese escenario le adicionamos que el art. 304 bis remite únicamente a los arts. 5 . Uno y 7.Dos de la LOFPP, es decir, circunda el delito de financiación ilegal a las donaciones privadas y a las que superen el límite cuantitativo de los 100.000 euros (cuando la financiación provenga de Gobiernos y organismos, entidades o empresas públicas extranjeras o de empresas directamente vinculadas con los mismos), parece que no existe la financiación ilícita con origen en la Administración. Extremo que resulta verdaderamente incomprensible. No obstante, a pesar de que ello no sea constitutivo de delito en sentido estricto, creo que se trata de unas situaciones que pueden ser reconducidas al ámbito de alguno de los delitos contra la Administración Pública, ya sea el cohecho, la prevaricación, la malversación o el tráfico de influencias.

82 1. Subvenciones públicas para gastos electorales, 2. Subvenciones estatales anuales para gastos de funcionamiento, 3. Subvenciones anuales que las CCAA establezcan para gastos de funcionamiento en el ámbito autonómico correspondiente, 4 . Subvenciones extraordinarias para realizar campañas de propaganda que puedan establecerse en la Ley Orgánica reguladora de las distintas modalidades de referéndum, 5. Aportaciones que, en su caso, los partidos políticos puedan recibir de los Grupos Parlamentarios de las Cámaras de las Cortes Generales, Asambleas Legislativas de las Comunidades Autónomas, Juntas Generales y de los Grupos de Representantes en los órganos de las Administraciones locales.

83 Art. 17.Uno. "Sin perjuicio de las responsabilidades legales de cualquier índole que se deriven de lo dispuesto en el ordenamiento jurídico en general y de lo preceptuado en esta ley en particular, el Tribunal de Cuentas acordará la imposición de sanciones al partido político que cometa alguna de las infracciones que se tipifican en este artículo, siempre que no constituyan delito..." 


\section{Bibliografía}

BUSTOS RUBIO, M., "El nuevo delito de financiación ilegal de partidos políticos", en Revista Penal, n 37, 2016.

CÓRDOBA RODA, J., en Comentarios al Código penal. Parte General, (CÓRDOBA RODA-J.-GARCÍA ARÁN, M., Directores), Madrid, 2011.

DE ÁNGEL YÁGÚEZ, R., La doctrina del levantamiento del velo de la persona jurídica en la jurisprudencia, $6^{\mathrm{a}}$ edición, Pamplona, 2013.

DOVAL PAÍS, A., Posibilidades y límites para la formulación de las normas penales. El caso de las leyes en blanco, Valencia, 1998.

GARCÍA ARÁN, M., "Remisiones normativas, leyes penales en blanco y estructura de la norma penal", en Estudios penales y Criminológicos, XVI, 1992-1993.

GARCÍA ARÁN, M., "Sobre la tipicidad penal de la financiación irregular de los partidos políticos", en Derecho penal para un Estado Social y Democrático de Derecho (Estudios penales en homenaje al Profesor Emilio Octavio de Toledo y Ubieto), Madrid, 2016.

GERPE LANDÍN, M., "Principio de legalidad y remisiones normativas en materia penal", en Revista Jurídica de Cataluña, 1991.

GÓMEZ BENÍTEZ, J.M. "Financiación ilegal de partidos políticos y corrupción", en Prevención y tratamiento punitivo de la corrupción en la contratación, (CASTRO MORENO, A.-OTERO GONZÁLEZ, P., Directores), Madrid, 2016.

HUERTA TOCILDO, S., "Principio de legalidad y normas sancionadoras", en El principio de legalidad. Actas de las $V$ Jornadas de la asociación de Letrados del Tribunal Constitucional, Madrid, 2000.

JAVATO MARTÍN, A., en Comentarios Prácticos al Código Penal (GÓMEZ TOMILLO, M., Director), $3^{\text {a }}$ edición, Pamplona, 2016. 
LEÓN ALAPONT, J., "La responsabilidad penal de los partidos políticos en España. ¿Disfuncionalidad normativa?, en Revista General de Derecho Penal, n 27, 2017.

LUZÓN PEÑA, D.M., Lecciones de Derecho Penal, $3^{\mathrm{a}}$ edición, ampliada y revisada, Valencia, 2016.

MACÍAS ESPEJO, B., "Sobre la incriminación de la financiación ilegal de partidos políticos en el artículo 304 bis del Código penal", en Cuadernos de Política Criminal, núm. 119, 2016.

MALEM SEÑA J.F., La corrupción. Aspectos éticos, económicos, políticos y jurídicos, Barcelona, 2002.

MAROTO CALATAYUD, M., La financiación ilegal de los partidos políticos. Un análisis político-criminal, Madrid, 2015.

MAROTO CALATAYUD, M., "Financiación ilegal de partidos políticos", en Comentario a la reforma penal de 2015, (QUINTERO OLIVARES, G., Director), Pamplona, 2015.

MIR PUIG, S., Derecho penal. Parte General, $10^{\mathrm{a}}$ ed. (2 $2^{\mathrm{a}}$ reimpresión), 2016.

MUÑOZ CONDE, F., Derecho Penal. Parte Especial, 20ª edición, Valencia, 2015

MUÑOZ CUESTA, F.J., "Delitos de financiación ilegal de partidos políticos", en Revista Aranzadi Doctrinal, núm. $5 / 2015$.

NAVARRO CARDOSO, F., "Corrupción, transparencia y Derecho penal. Especial referencia al derecho de acceso a la información pública", en Cuadernos de Política Criminal, núm. 114, 2014.

NIETO MARTÍN, A., "Financiación ilegal de partidos políticos (arts. 10-13)", en Fraude y corrupción en el Derecho penal económico europeo. Eurodelitos de corrupción y fraude, (ARROYO ZAPATERO, L.- NIETO MARTÍN, A., Coordinadores) Cuenca, 2006.

NÚÑEZ CASTAÑO, E., "La cuestionable regulación penal de los delitos de financiación ilegal de partidos políticos", en Revista Penal, $\mathrm{n}^{\mathrm{o}}$ 39, 2017. 
OLAIZOLA NOGALES, I., La financiación ilegal de los partidos políticos: un foco de corrupción, Valencia, 2014.

OLAIZOLA NOGALES, I., "Las reformas legales relacionadas con la financiación de los partidos políticos", en Corrupción pública prueba y delito: cuestiones de libertad e intimidad (JAREÑO LEAL. A. -DOVAL PAÍS, A. Directores), Pamplona, 2015.

OLAIZOLA NOGALES, I., "El delito de financiación ilegal de partidos políticos en la reforma del CP", en Diario La Ley, $\mathrm{n}^{\circ}$ 8516, 10 de abril de 2015, Ref. D-141.

PUENTE ABA, L.M., "Financiación ilegal de partidos políticos (art. 304 bis CP)", en Comentarios a la reforma del Código penal de 2015 (Director, GONZÁLEZ CUSSAC, J.L.), Valencia, 2015.

ROMERO FLORES, B., Partidos politicos y responsabilidad penal. La financiación electoral irregular, Barcelona, 2005.

SÁINZ-CANTERO CAPARRÓS, J.E., "Los delitos de financiación ilegal de los partidos políticos", en Estudios sobre el Código penal reformado (MORILLAS CUEVA, L., Director), Madrid, 2015.

SANDOVAL, J.C. "Aportación a una reflexión político criminal sobre la corrupción en la financiación de los partidos políticos", en Revista General de Derecho Penal, $\mathrm{n}^{\mathrm{0}} 22$, 2014.

SANTANA VEGA, D.M., El concepto de ley penal en blanco, Buenos Aires, 2000. 